\title{
Drones of Apis dorsata (Fabricius 1793) congregate under the canopy of tall emergent trees in Borneo
}

\author{
N Koeniger ${ }^{1}$, G Koeniger ${ }^{1}$, S Tingek 2, A Kalitu 2, M Mardan ${ }^{3}$ \\ 1 Institut für Bienenkunde (Polytechnische Gesellschaft), Fachbereich Biologie der JW Goethe- \\ Universität Frankfurt a M, Karl-von-Frisch-Weg 2, 61440 Oberursel, Germany; \\ ${ }^{2}$ Agricultural Research Station Tenom, PO Box 197, 89908 Tenom, Sabah, Malaysia; \\ ${ }^{3}$ Dept Plant Protection, University Pertanian Malaysia, 43400 Serdang, Selangor, Malaysia
}

\begin{abstract}
Summary - The drones of Apis dorsata performed their mating flights at dusk. They took off simultaneously from the colonies. The flying drones produced a distinct hum which was clearly audible. By following this flight noise on several consecutive days, a drone congregation area (DCA) was located under the canopy of a high emergent tree. There, the drone's hum was regularly heard at the expected time and several $A$ dorsata drones were caught. Under the canopy the drones were attracted to a queen dummy impregnated with queen pheromone. Dummies outside the canopy or above the tree did not attract any drones. Further, drone attractivity showed a clear maximum several meters below the canopy. Under the canopy of other emergent tall trees three more DCAs were detected. At another place one observation on a slope of a mountain resulted in the detection of a DCA downhill in the valley. No drones were found under tall trees on the slope. In $A$ mellifera and $A$ cerana the factors that cause the drones to congregate at a distinct place are still unknown. So, the clear feature of the $A$ dorsata DCA in Borneo involving a landmark is unique. Observations from other parts of the extended natural distribution of $A$ dorsata in Asia are required to confirm whether the drones of this species generally congregate under the canopy of emergent tall trees.
\end{abstract}

reproduction / flight / A dorsata / Borneo / drone congregation area

\section{INTRODUCTION}

Mating of honeybee queens and drones takes place during flight at some distance from the colony. Because direct observations of mating behaviour are rare (Woyke and Ruttner, 1958; Koeniger, 1988), our knowledge of reproduction in the genus Apis is based mainly on 'indirect' evidence. Sperm counts in drones and queens after mating flight, anatomical studies and genetic diagnosis of offspring indicate that female polyandry and male monogamy is common in all species of Apis. The need of the polyandrous queen to mate with multiple drones during her short mating flight period seems to have favoured the evolution of 
drone congregation areas (DCA) in several species of Apis (Koeniger and Koeniger, 1991).

In $A$ dorsata two mio spermatozoa are produced by one drone (Koeniger et al, 1990) and up to six mio spermatozoa were found in an egg-laying queen's spermatheca (own data). These results support the existence of multiple mating in $A$ dorsata. However, many other features of the reproductive behaviour and the question of whether $A$ dorsata drones congregate at special places (DCA) are still unknown.

\section{MATERIALS AND METHODS}

Our observations and experiments were carried out in Borneo at the Agricultural Research Station, near Tenom (Sabah, Malaysia) from December 1992 to March 1993. Two pairs of binoculars (10 $\times 40$, Carl Zeiss, Germany and 12 × 50, Zenith, UDSSR) were used to observe drones at the colonies and at the DCA.

As a queen dummy we used a small piece of a black pencil (length $3.4 \mathrm{~cm}$, diameter $8 \mathrm{~mm}$ ). A cotton thread was wound six times around the middle of the stick resulting in a small cotton belt. We impregnated the belt with $0.1 \mathrm{ml}$ acetone containing $1 \mathrm{mg}$ synthetic 9-oxo-2-trans decenoic acid (9-OD). The dummy was fixed to the line $2 \mathrm{~m}$ below a hydrogen-filled balloon.

\section{RESULTS}

\section{Bee tree 1}

For many years, some trees in Tenom Agricultural Research Station have regularly harboured colonies of $A$ dorsata. Bee tree 1 (Albizia falcataria) is located in the plain (flat) valley of the Pegalan river surrounded by two rows of hills that were $1-2 \mathrm{~km}$ to the east and $20 \mathrm{~km}$ to the west (fig 1). With a height of $48 \mathrm{~m}$ bee tree 1 was the tallest among a group of surrounding Albizia fal- cataria. These belong to the fastest growing trees (Corner, 1988). They were planted in 1977 to serve as shade trees for cocoa plants. During our research bee tree 1 had between 23 and 28 A dorsata colonies. Most of the colonies built their comb on the lower, horizontal branches at a height of $17.5 \mathrm{~m}$ to $35 \mathrm{~m}$ above the ground.

\section{Drone flight time and drone's hum}

In Sabah drones of $A$ dorsata flew during dusk between 18.30 and 18.50 (Koeniger et al, 1988). From the ground we observed the start of the drones at colonies of bee tree 1 using a binocular. We observed a large number of dark points emerging from the comb's surface. They became airborn and rapidly disappeared among the surrounding branches. The take-off flight was accompanied by a typical drones' hum which was clearly audible and distinctly different from the worker's flight sound. The hum started suddenly with initially high intensity. Then the hum decreased but remained audible on a low level during the whole period of drone flight activity. Shortly before the end of the drone's flight period the hum became louder again before it ceased.

About $13 \pm 2$ min after the start the hum was over ( $n=14$ days). At that time it was already totally dark.

\section{Tracking the drone's hum}

During the drone flight period we circled at some distance $(100 \mathrm{~m})$ around bee tree 1 and tried to listen to determine the direction in which the main portion of the drones were traveling. After confirming the main flight direction at this place after 2 more days, we proceeded to another location in a straight line away from bee tree 1 . There again we confirmed the hum of drones passing over our heads for 2 days. We thus found DCA 1 in several likewise steps (fig 1). Beyond this 
place (DCA 1) no hum was audible for 4 days.

\section{Description of DCA 1}

DCA 1 was situated at the north-west corner of field 40 (fig 1) on a cocoa plantation. The distance to bee tree 1 was $700 \mathrm{~m}$. The center of the drone's hum was under the canopy of a tall $(47 \mathrm{~m})$ Albizia falcataria. This tree, together with two nearby trees, was distinctly taller than all surrounding trees. Viewing from the north at some distance we saw the prominent shape of these trees emerging out of the tree line (fig 2).

\section{Comparison of drone flight at bee tree 1 and DCA 1}

At DCA 1 the drone's hum started within 2 min after the time of the drone's departure from bee tree 1 and remained constantly strong. The end of the hum was about 1-3 min earlier at DCA 1 than at bee tree 1 . The time of the drone's hum at bee tree 1 (colonies) and at DCA 1 was compared and found to match closely (table I).

\section{Trapping drones at DCA 1}

To confirm the identity of the species we tried to catch some $A$ dorsata drones. The following $A$ mellifera drone catching techniques were tested and some new methods were developed:

1) A mellifera drone traps (Taylor, 1984; Williams, 1987) were not successful. Many drones entered the trap when it was high up under the canopy. But the drones apparently had only little difficulty to fly downward and to exit from the trap before we succeeded in pulling it to the ground. In only two out of 14 attempts we caught one and eight drones respectively.

2) We presented a copulation dummy (Koeniger et al, 1989) which was prepared out of a dead $A$ mellifera queen with an open sting chamber contaminated by $1 \mathrm{mg} 9-\mathrm{OD}$. In each of five trials at least one $A$ dorsata drone copulated with the $A$ mellifera queen dummy and got stuck (fig 3 ).

3) An adaptation from an $A$ cerana mating study (Fujiwara et al, 1994) was to fix a piece of fly ribbon behind the dummy. In all 5 trials we found several (2-5) drones stuck to the glue of the ribbon.

4) Most effective in catching larger numbers of drones was the sticky thread method. We fixed a cotton thread behind the dummy, which was thickly covered with insect glue (Fujitangle, Fuji Pharmaceutical Nakonotokyo, Japan). Many drones flying to the dummy were temporarily caught by the sticky thread and some glue was smeared on their wings. Large numbers of these drones fell to the ground, where the crawling and buzzing $A$ dorsata drones were collected in the beam of an electric torch. On average we found about 30 drones after a presentation of the dummy with the sticky thread in the center of the DCA for $5 \mathrm{~min}$. Only $A$ dorsata drones were caught, no $A$ dorsata workers or other insects.

\section{Distribution of drones of DCA 1}

The drone's hum had its highest intensity under the canopy of the tall tree. Moving away from the tree the hum became lower until, at a distance of $40 \mathrm{~m}$ from the tree, it was not audible anymore. For a more detailed study we used dummies which we lifted to a height of $18 \mathrm{~m}$ by a hydrogenfilled balloon (Ruttner and Ruttner, 1965a). The number of drones gathering around the dummy were counted using binoculars. We did not notice any drones at the dummies, which were in the open, beyond the cover of the tree's canopy. At the same time we counted regularly many drones at the dummy under the canopy (24 comparative counts, four exchanges of dummies, 3 days). Further, we carefully maneuvered 
the balloon 8-10 $\mathrm{m}$ above the tree top. No drones flew at the dummy above the tree while the dummy under the canopy was frequently visited by drones (12 comparative counts, no changes of dummies, 1 day).

Even with a slight breeze the balloon changed its position and often it drifted into the branches of neighbouring trees and got torn. So we put up a rope loop over a high $(38 \mathrm{~m})$ branch of the tree on DCA 1. Several queen dummies were fixed to the rope. The distance between the dummies was $2.5 \mathrm{~m}$. We pulled them up until the first dummy had reached the lowest branch. The drones gathered around the dummies and showed an optimal reaction several meters below the canopy (fig 4 ) at heights of $17.5 \mathrm{~m}$ and $20 \mathrm{~m}$.

At DCA 2 we performed similar experiments. Again the maximal drone attraction was found at dummies several meters below the canopy (table II).

\section{Other DCAs}

The main feature of DCA 1 as a landmark was the emergent high tree top. Using this criterion we located three more trees in the experimental area where we checked for $A$ dorsata drones (fig 1). Under all three trees we heard the drone's hum at the expected time and we caught $A$ dorsata drones using the sticky thread technique. The DCAs seemed to be more or less randomly scattered around bee tree 1 .

\section{Bee tree 2}

At a slope overlooking the same valley ( 8 $\mathrm{km}$ south of bee tree 1) we found bee tree 2 (Parkia speciosa). It was a single tall tree $(30 \mathrm{~m})$ within an area of low vegetation (bushes and fields). Eight colonies had attached their combs to the lower branches at a height of $15 \mathrm{~m}$. Looking from the posi- tion of bee tree 2 we saw a tall outstanding tree top in the west, down in the valley in a distance of about $1.5 \mathrm{~km}$. Further, a tall tree was visible in the north at the same height on the slope as bee tree 2 at $1 \mathrm{~km}$. We observed the drone's flight at bee tree 2 and waited at both places under the canopy of the outstanding trees. Only in the valley we heard the drone's hum and detected a DCA. No drones were heard under the tall tree on the slope.

\section{DISCUSSION}

The first DCAs of $A$ mellifera in Europe and USA were discovered by hearing (accidentally) the hum of flying drones (Jean-Prost, 1957; Zmarlicki and Morse, 1963; Ruttner and Ruttner, 1965a). But tracking the starting drones from the colony to the DCA by means of sound was never described. This new technique seems to depend on specific behavioural characteristics of $A$ dorsata drones:

1) Nearly all drones of the colonies take off for mating flight simultaneously. Large numbers of drones seem to move away in densely packed formations.

2) During the time of drone flight at sun-set there is generally not much foraging activity. The flight sound of worker bees does not overlap.

3) Drones are not dependent on weather conditions and fly nearly every day.

4) The flying altitude of the $A$ dorsata drones is low enough to detect (hear) the main flight direction.

Tracking the hum from bee tree 1 to DCA 1 evidenced a drone flight distance of $700 \mathrm{~m}$ in the first case. The short distance corresponds well to the very short flight period of $15 \mathrm{~min}$. Further, the comparison of the departure time at bee tree 1 and the arrival at DCA 1 (table I) supports this observation. However, we can not exclude that sev- 
eral other sections of the drone population of bee tree 1 flew to other DCAs, including the ones which we located in close proximity. At same time the emergent tall tree top of DCA 1 may have attracted several drones from colonies of other nesting locations in the area.

Compared to $A$ mellifera drones which visit a DCA from a distance of up to $5 \mathrm{~km}$ in large numbers (Ruttner and Ruttner, 1965b, 1972) our observations indicate a significantly shorter drone flight distance for $A$ dorsata drones. But general conclusions on the mating flight distance of $A$ dorsata will require more and different experiments. Drones must be marked at the colony and recaptured at the DCA or vice versa (Ruttner and Ruttner, 1966). The effective defense behaviour of this large honeybee species (Lindauer, 1956) and the nesting place of the colonies high up in trees will pose a great challenge to any daring researcher who thinks of marking and recapturing drones of $A$ dorsata.

In the three Apis species ( $A$ mellifera, $A$ cerana, $A$ dorsata) drones accumulate above certain areas. Only within these locations, the humming noise of flying drones is audible. Inside the DCA, drones are attracted and try to copulate with dummies impregnated by 9-OD. The attraction to the dummies shows a clear vertical optimum. Further, our observations indicate that the optimal altitude might be connected to height of the canopy as in A cerana in Sri Lanka (Punchihewa et al, 1990), though optimal height of drone flight in Sri Lanka and the height of the trees was much lower $(6-8 \mathrm{~m})$. Drones do not react to a dummy beyond the borders of the DCA. DCAs are visited by drones from many colonies in the area (Ruttner and Ruttner, 1966; Punchinewa et al, 1990). So, the function of a DCA as a genetic 'out breeding' mechanism seems to be common in the three species.

However, as concerns some features, the DCAs of $A$ dorsata show differences compared to the DCAs of the other honey bees. The space in which the drones of $A$ dorsata accumulate is covered by a dense and high canopy. A cerana indica drones in Sri Lanka congregate in coconut or rubber plantations or other areas with trees. But they assemble in an open space among canopies of trees and fly with direct sight to the sky. A cerana japonica drones congregate above tall trees in Japan (Fujiwara et al, 1994) and A cerana cerana drones of imported colonies originating from NorthWest-Frontier-Province, Pakistan were found at an A mellifera DCA near Oberursel in Germany (Ruttner, 1973). So three races of $A$ cerana and European $A$ mellifera drones are reported to fly under the blue sky (Jean-Prost, 1957; Zmarlicki and Morse, 1963).

The area of an $A$ mellifera DCA was estimated as $2000 \mathrm{~m}^{2}$ to $12000 \mathrm{~m}^{2}$ (Ruttner and Ruttner, 1965). The actual area of $A$ mellifera drone distribution measured by radar is reported to be $1600 \mathrm{~m}^{2}$ (Loper et al, 1987). This size is much larger than the $A$ cerana DCA but similar to the size of $A$ dorsata DCAs.

We still do not know whether $A$ dorsata drones will visit the same place for several years. Large trees and outstanding canopies exist for many years and will enable us to continue our observations.

In A mellifera (Ruttner, 1985) and in $A$ cerana (Punchihewa et al, 1990) it is still unknown which environmental factors cause drones to congregate at a distinct place. So the clear and very obvious feature of the $A$ dorsata DCA as a landmark is unique. All (five) outstanding trees were checked in our experimental area and were visited by $A$ dorsata drones. Further, a preliminary observation at a location where the colonies were nesting at the slope of a mountain indicates that apparently drones fly downward and visit outstanding trees in the valley.

We hope that this publication will encourage observations and experiments in other 
parts of the extended natural distribution of $A$ dorsata. Such evidence will determine whether the drones of the largest honey bee species generally congregate under the canopy of emergent tall trees.

\section{ACKNOWLEDGMENTS}

We dedicate this publication to Friedrich Ruttner on occasion of his 80th birthday, on May 15th, 1994 and sincerely acknowledge his outstand- ing contributions to research of DCAs. F Ruttner, who took G Koeniger and N Koeniger in 1965 to the Seekopfsattel (the classical DCA in the Austrian Alpes), has inspired this research. His vivid interest resulted in several letters to Tenom with valuable suggestions and advice. Donson Simin, officer in charge of ARS Tenom, generously gave us logistic and technical support. Tadaharu Yoshida, Tamagawa University Japan, answered our urgent requests without delay and sent several small but essential items for our work. Stefan Fuchs and Steve Sheppard have assisted in improving earlier versions of this publication.

\title{
Drohnensammelplätze der Riesenhonigbiene (Apis dorsata Fabricius 1793) unter dem Laubdach von hohen, herausragenden Bäumen in Borneo
}

\begin{abstract}
Zusammenfassung - Bei Beginn der Dämmerung starteten die Drohnen von $A$ dorsata gleichzeitig von den Waben. Dabei erzeugten sie einen sehr gut wahrnehmbaren typischen Drohnenflugton. Über mehrere Tage konnte die Flugbahn der Drohnen auf Grund des Flugtones bis zum Auffinden des ersten Drohnensammelplatzes verfolgt werden. Die Drohnen sammelten sich unter dem Laubdach eines hohen Baumes. Auf diesem Drohnensammelplatz wurden einige A dorsata Drohnen gefangen. Unter dem Laubdach wurden die Drohnen mit einer Königinnenattrappe angelockt. Dagegen wurden Vergleichsattrappen von Drohnen nicht angeflogen, die seitlich außerhalb des Laubdaches oder über der Krone des Baumes geboten wurden. Die Attraktivität der Attrappen hatte einige Meter unterhalb der tiefsten Äste des Baumes ein Maximum. Insgesamt überprüften wir fünf große herausragende Bäume in unserem Versuchsgelände. Auf allen Plätzen war der typische Flugton zur erwarteten Zeit deutlich hörbar und wir konnten $A$ dorsata Drohnen mit der Klebfadenmethode fangen. Damit ist der klare Charakter dieser Bäume als Landmarke für den $A$ dorsata Drohnensammelplatz auf Borneo nachgewiesen. Vermutlich werden sich auch in anderen Teilen Asiens die Drohnen der Riesenhonigbiene unter der Krone von herausragenden Bäumen versammeln.
\end{abstract}

\section{Reproduktion / Flug / A dorsata / Borneo / Drohnensammelplatz}




\section{EINLEITUNG}

Die Paarung von Königin und Drohnen der Honigbiene findet stets im freien Fluge in einiger Entfernung zum Bienenvolk statt. Daher sind direkte Beobachtungen der Paarung selten (Woyke and Ruttner, 1958; Koeniger, 1988). Unsere Kenntnisse von der Reproduktion in der Gattung Apis beruhen in erster Linie auf indirekten Nachweisen. Zählungen von Spermatozoen in Drohnen und Königinnen nach dem Hochzeitsflug, anatomische Untersuchungen der Geschlechtsorgane und die genetische Analyse von Nachkommen deuten darauf hin, daß die Mehrfachpaarung der Königin und die Monogamie des Drohns wohl bei allen Arten vorkommen. Die Notwendigkeit der Paarung der Königin mit vielen Drohnen während eines kurzen Hochzeitsfluges hat vermutlich die evolutive Entwicklung von Drohnensammelplätzen gefördert (Koeniger und Koeniger, 1991).

Ein A dorsata Drohn produziert zwei mio Spermatozoen. Bis zu sechs mio Spermatozoen wurden in der Spermatheka von legenden Königinnen gefunden (Koeniger et al, 1990). Damit ist die Mehrfachpaarung auch für die Königin von $A$ dorsata nachgewiesen. Aber die Frage ist ungeklärt, ob sich auch die Drohnen der Riesenhonigbiene regelmäßig auf bestimmten Sammelplätzen treffen.

\section{MATERIAL UND METHODE}

Die Arbeiten wurden auf der landwirtschaftlichen Versuchsstation Tenom auf Borneo von Dezember 1992 bis März 1993 durchgeführt. Zwei Ferngläser $(10 \times 40$, Carl Zeiss, Germany und $12 \times$ 50 , Zenith, UDSSR) wurden zur Beobachtung der Bienenvölker und der Drohnen benutzt.

Als Königinnenattrappen wurden kurze Abschnitte von schwarzen Bleistiften (Länge 3,4 $\mathrm{cm}$, Durchmesser $0,8 \mathrm{~cm}$ ) benutzt. In der Mitte wurde die Bleistiftabschnitte eingekerbt und sechsmal mit einem Baumwollfaden umwickelt, so daß ein kleiner Gürtel entstand. Hier trugen wir vor dem Versuch $0,1 \mathrm{ml}$ Aceton auf, in dem $1 \mathrm{mg}$ synthetische 9-oxo-2-trans Decensäure (9-OD) gelöst war. Die Attrappe wurde dann etwa $2 \mathrm{~m}$ unterhalb eines mit Wasserstoffgas gefüllten BalIons an der Schnur befestigt.

\section{ERGEBNISSE}

\section{Bienenbaum 1}

Seit vielen Jahren gab es in der Station Tenom verschiedene Bäume, die regelmäßig einzelne oder mehrere Völker von $A$ dorsata beherbergten. Wir wählten für unsere Beobachtungen Bienenbaum 1, der sich im ebenen Tal des Pegalan Flusses befand. Im Osten liegen die das Tal begrenzenden Hügel in $2 \mathrm{~km}$ Entfernung, die westliche Hügelkette dagegen ist ca $20 \mathrm{~km}$ entfernt.

Mit einer Höhe von 48 m war Bienenbaum 1 deutlich größer als die umgebenden Bäume. Alle dort vorhandenen Bäume gehören zur selben Art, Albizia falcataria, die als ein sehr schnell wachsender Baum gilt (Corner, 1988). Die Bäume wurden 1977 als Schattenspender für Kakaopflanzen gesetzt. Während unserer Arbeiten waren zwischen 23 und 28 A dorsata Völker im Bienenbaum 1 vorhanden. Die meisten Völker hatten ihre Waben an den unteren, mehr oder weniger horizontalen Ästen in einer Höhe von $17,5 \mathrm{~m}$ bis $35 \mathrm{~m}$ gebaut.

\section{Drohnenflugzeit und Flugton}

In Sabah fliegen die Drohnen von $A$ dorsata in der Dämmerung von 18.30 bis 18.50 (Koeniger et al, 1988). Regelmäßig wurde der Start der Drohnen vom Boden aus mit Ferngläsern beobachtet: wir sahen dann gleichzeitig eine sehr große Zahl von schwarzen Punkten aus der Oberfläche der Wabe auftauchen. Die einzelnen Punkte 
waren nur für weniger als eine Sekunde sichtbar, bevor sie im Geäst der Baumkronen verschwanden. Der Start der Drohnen war durch einen sehr typischen Drohnenflugton gekennzeichnet, der sich deutlich von dem eher leisen Fluggeräusch der Arbeiterinnen unterschied. Der Drohnenflugton begann plötzlich und zunächst mit hoher Lautstärke. Später, nach ca 5 min, wurde der Ton am Bienenbaum 1 leiser aber blieb während der gesamten Flugperiode hörbar. Kurz vor Ende stieg mit der Rückkehr der Drohnen die Lautstärke wieder an. Etwa $13 \pm 2$ min nach dem Start war kein Drohnenflugton mehr wahrnehmbar. Das konnte für 14 Beobachtungstage bestätigt werden.

\section{Die Verfolgung der fliegenden Drohnen}

Während des täglichen Abfluges der Drohnen umkreisten wir Bienenbaum $1 \mathrm{im}$ Abstand von ca $100 \mathrm{~m}$. Dabei wurde mit dem Gehör die Hauptabflugrichtung auf Grund des Drohnenflugtones festgestellt. An weiteren Versuchstagen wurde die Richtung bestätigt und genauer festgelegt. Nun wurde in $300 \mathrm{~m}$ Entfernung vom Bienenbaum 1 ein neuer 'Hörpunkt' in Richtung des Drohnenfluges festgelegt und wiederum an drei Versuchstagen die Richtung der über unsere Köpfe fliegenden Drohnen herausgehört. Auf diese Weise wurde in mehreren Schritten der Drohnensammelplatz 1 (Abb 1) gefunden. Jenseits dieses Platzes konnten wir an vier Versuchstagen keinen Drohnenflugton wahrnehmen.

\section{Drohnensammelplatz 1}

Drohnensammelplatz 1 lag in der nordwestlichen Ecke von Feld 40 (Kakaoplantage). Die Entfernung zum Bienenbaum 1 betrug $700 \mathrm{~m}$. Das Zentrum des Drohnenflugtones befand sich unter dem Laubdach eines großen Albizia falcataria von $47 \mathrm{~m}$ Höhe. Der Baum ragte gemeinsam mit zwei westlich stehenden Nachbarbäumen über die anderen Bäume hinaus. Die Ansicht vom Norden her zeigt die über die Baumlinie hinausragenden Kronen dieser Baumgruppe (Abb 2).

\section{Drohnenflugzeit am Bienenbaum 1 und Drohnensammelplatz 1}

Am Drohnensammelplatz 1 begann der Drohnenflugton ca 2 min später als am Bienenbaum 1. In der Folge hielt der Drohnenflugton am Sammelplatz während der gesamten Flugzeit eine hohe Intensität und war sehr gut hörbar. Am Ende der Drohnenflugzeit verstummte der Summton am Drohnensammelplatz 1 etwa eine Minute früher als am Bienenbaum 1. Der Vergleich der Zeiten ergab eine gute Übereinstimmung und sprach für die Annahme, daß die Drohnen von Bienenbaum 1 zum Drohnensammelplatz 1 flogen (Tabelle I).

\section{Drohnenfang auf dem Drohnensammelplatz 1}

Es wurden verschiedene von A mellifera bekannte Drohnenfangmethoden getestet und neue Techniken entwickelt:

1) A mellifera Drohnenfallen (Taylor, 1984; Williams, 1987) bewährten sich nicht. Zunächst sammelten sich im Zentrum des Platzes und hoch unter dem Laubdach viele Drohnen in der Falle. Aber die Tiere hatten dann - anders als A mellifera Drohnen keine Schwierigkeiten nach unten zu fliegen und den Weg aus der Falle herauszufinden, sobald die Falle heruntergeholt wurde. Nur in zwei von insgesamt 14 Versuchen wurden ein bzw acht Drohnen gefangen.

2) Eine Kopulationsattrappe (Koeniger et al, 1989) wurde aus einer konservierten $A$ mellifera Königin hergestellt und mit geöffneter Stachelkammer auf dem Drohnensammelplatz 1 präsentiert. In fünf Versuchen kopulierte jeweils mindestens ein Drohn 
und blieb verhängt in der Attrappe stecken (Abb 3).

3) In Abänderung der für $A$ cerana beschriebenen Methode (Fujiwara et al, 1994) wurde ein kleiner Streifen Fliegenpapier hinter der Attrappe befestigt. In allen fünf Versuchen blieben einige (2-5) Drohnen auf dem Fliegenpapier kleben und konnten nach Einholen des Ballons eingesammelt werden.

4) Am erfolgreichsten verliefen die Versuche mit der Klebefaden-Methode. Ein dünner Baumwollfaden wurde hinter der Attrappe befestigt, der reichlich mit Insektenkleber (Fujitangle, Fuji Pharmaceutical Nakonotokyo, Japan) bestrichen wurde. Viele Drohnen blieben zunächst im Anflug auf die Attrappe für kurze Zeit am Faden hängen. Dabei wurde der Klebstoff vom Faden auf die Flügel und den Körper 'verschmiert', so daß viele Drohnen ihre Flugfähigkeit einbüßten und zu Boden fielen. Dort konnten die summenden und herumkriechenden Tiere im Lichtkegel einer Taschenlampe eingesammelt werden. Meist waren nach einer Exposition der Attrappe mit dem Klebefaden im Zentrum der Drohnenansammlung von nur 5 min ca 30 Drohnen abgestürzt und eingesammelt. In allen Versuchen wurden ausschließlich $A$ dorsata Drohnen, keine $A$ dorsata Arbeiterinnen und keine anderen Insekten gefangen.

\section{Drohnenverteilung auf dem Drohnensammelplatz}

Der Drohnenflugton war unter der Krone des Baumes am lautesten. Bei einer schrittweisen Entfernung vom Intensitätsmaximum wurde der Ton leiser und nach einem Abstand von 40-50 m war der Drohnenflugton nicht mehr wahrnehmbar. Für die genauere Beschreibung der Drohnenverteilung wurden Attrappen mit einem Wasserstoffballon auf ca $18 \mathrm{~m}$ Höhe gehoben (Ruttner and Ruttner, 1965a) und mit einem Fernglas beobachtet. Die Zahl der anflie- genden Drohnen wurde pro Minute einmal gezählt. Wir konnten keine Drohnenanflüge außerhalb (seitlich) der Baumkrone unter freiem Himmel feststellen. Zur gleichen Zeit zählten wir regelmäßig zahlreiche anfliegende Drohnen unter dem Blätterdach des Baumes (24 gleichzeitige Zählungen, vier Wechsel der Attrappen, drei Versuchstage). Weiter wurde ein Ballon vorsichtig 8-10 m über die Baumkrone manövriert. Es wurden keine Drohnen an der Attrappe über dem Baum gesichtet, während gleichzeitig unter den Ästen die Attrappe regelmäßig angeflogen wurde (12 gleichzeitige Zählungen, kein Attrappenwechsel, 1 Versuchstag).

Schon ein schwacher Wind verdriftete den Ballon und häufig verfing sich die Leine im Gebüsch und den umstehenden niedrigeren Bäumen. Daher zogen wir ein stärkeres Seil über einen Ast des Baumes in ca $38 \mathrm{~m}$ Höhe und verknoteten beide Enden des Seiles. Nun konnten mehrere Attrappen in 2,5 $\mathrm{m}$ Abstand voneinander am Seil festgemacht werden und soweit hochgezogen werden, bis die oberste Attrappe die ersten Äste der Baumkrone erreicht hatte. Die Drohnen flogen die Attrappen in Abhängigkeit von der Höhe an. Die größte Attraktivität wurde einige Meter unter dem Laubdach an den Attrappen in $20 \mathrm{~m}$ und $17,5 \mathrm{~m}$ Höhe festgestellt (Abb 4). Die gleichen Versuche wurden am Drohnensammelplatz 2 (Abb 1) an 3 Tagen wiederholt und ergaben gleichfalls ein deutliches Attraktivitätsmaximum bei $14 \mathrm{~m}$, also $5 \mathrm{~m}$ unterhalb der Baumkrone (Tabelle II).

\section{Weitere Drohnensammelplätze}

Das Hauptmerkmal beider Drohnensammelplätze von $A$ dorsata war die über die allgemeine Vegetation herausragende Baumkrone. Nach diesem Merkmal wurden drei weitere Bäume in der näheren Umgebung ausgewählt und auf Drohnenanflug geprüft (Abb 1). Unter allen drei Bäumen 
konnten wir zur entsprechenden Zeit den Drohnenflugton hören und mit der Klebefadenmethode $A$ dorsata Drohnen fangen. Die Drohnensammelplätze waren anscheinend mehr oder weniger zufällig um Bienenbaum 1 verteilt.

Am Hang eines Berges, der sich ca $8 \mathrm{~km}$ südlich vom Bienenbaum 1 befand wurde Bienenbaum 2 gefunden. Es war ein einzeln stehender Baum (Parkia speciosa) von $30 \mathrm{~m}$ Höhe auf einer Fläche mit niedriger Vegetation (Felder and Büsche). Acht Bienenvölker hatten jeweils die Waben an den unteren Ästen von Bienenbaum 2 in einer Höhe von 15-18 m gebaut. Von Bienenbaum 2 aus gesehen waren zwei hochragende Baumkronen sichtbar. Der erste Baum war unten im Tal in etwa 1,5 km Entfernung. Die zweite Baumgruppe war auf dem Hang in etwa gleicher Höhe wie der Bienenbaum 2 in ca $1 \mathrm{~km}$ Entfernung. Der Drohnenflug wurde an Bienenbaum 2 beobachtet und nur eine Minute später wurde der Drohnenflugton unter dem Baum im Tal wahrgenommen. Unter den Bäumen am Hang dagegen warteten wir vergeblich. Demnach schienen die Drohnen von $A$ dorsata eine Flugrichtung nach unten ins $\mathrm{Tal}$ zu bevorzugen.

\section{DISKUSSION}

Die ersten Drohnensammelplätze von $A$ mellifera in Europa und den USA wurden (meist zufällig) über die Wahrnehmung des Drohnenflugtones entdeckt (Jean-Prost, 1957; Zmarlicki and Morse, 1963; Ruttner and Ruttner, 1965a). Aber das Aufspüren eines Drohnensammelplatzes über die Verfolgung des Flugtones der vom Volk abfliegenden Drohnen ist bisher nicht beschrieben. Diese Methode beruht wohl auf mehreren Besonderheiten des Flugverhaltens der $A$ dorsata Drohnen:

1) Nahezu alle Drohnen des Volkes starten gleichzeitig und fliegen in dichten Drohnenwolken $a b$.
2) Während der Zeit des Drohnenfluges, kurz vor Sonnenuntergang, scheint meistens eine Trachtpause einzutreten, so da $\beta$ das Fluggeräusch der Arbeiterinnen den Drohnenflugton nicht beeinträchtigt.

3) Die Drohnen scheinen weitgehend unabhängig von Wetterbedingungen zu sein. Die Drohnen fliegen an fast jedem Tag.

4) Die Flughöhe der Drohnen ist niedrig genug, um den Drohnenflugton und die Bewegungsrichtung des Tones deutlich zu erkennen.

Die Verfolgung der Drohnen vom Bienenbaum 1 zum Drohnensammelplatz 1 zeigt in diesem ersten Fall eine kurze Flugdistanz von $700 \mathrm{~m}$. Diese kurze Flugstrecke scheint gut zu der sehr kurzen Flugdauer der $A$ dorsata Drohnen zu passen, die täglich nur wenig länger als 13 min fliegen (Tabelle I). Dabei soll jedoch betont werden, daß wahrscheinlich auch andere Drohnengruppen vom Bienenbaum 1 auch zu anderen Drohnensammelplätzen fliegen, von denen wir einige in der näheren Umgebung finden konnten. Weiter vermuten wir wegen des sehr lauten Drohnenflugtones, daß durch die herausragende hohe Baumkrone von Drohnensammelplatz 1 Drohnen von anderen Nistplätzen angelockt werden.

Besonders im Vergleich zu den A mellifera Drohnen, die in erheblichen Mengen aus bis zu $5 \mathrm{~km}$ Entfernung auf den Drohnensammelplatz fliegen (Ruttner and Ruttner, 1965b, 1972), deuten unsere Befunde eher auf deutlich kürzere Flugdistanzen bei $A$ dorsata Drohnen hin. Für quantitative Aussagen zur Paarungsdistanz von $A$ dorsata sind mehr und auch andere Versuche notwendig. Drohnen müssen am Bienenvolk markiert und am Drohnensammelplatz wiedergefangen werden oder vice versa (Ruttner and Ruttner, 1966). In diesem Zusammenhang bedeutet das effektive Verteidigungsverhalten (Lindauer, 1956) und der Nistort von $A$ dorsata hoch oben im Geäst der Bäume eine große Herausforderung für wagemutige Kollegen. 
Bei den drei Apis-Arten ( $A$ mellifera, $A$ cerana, $A$ dorsata) versammeln sich die Drohnen regelmäßig zur arttypischen Tageszeit über bestimmten Plätzen. Nur innerhalb dieser Plätze ist der Drohnenflugton zu hören und die Drohnen reagieren nur dort auf Attrappen mit synthetischer 9-OD. Der Anflug der Drohnen zeigt ein klares Optimum in der Höhenverteilung. Unsere Ergebnisse zeigen, daß die optimale Attraktivität von der Höhe des Blätterdaches des Baumes abhängig sein kann, ähnlich wie von Punchihewa et al (1990) in Sri Lanka für $A$ cerana nachgewiesen. Drohnen reagieren nicht auf Attrappen außerhalb der Grenzen des Drohnensammelplatzes. Weiter scheint in allen Fällen der Sammelplatz von Drohnen aus vielen verschiedenen Völkern aufgesucht zu werden, so daß seine Bedeutung in einer Vermeidung von Inzucht für alle drei Arten gesehen werden kann.

In anderen Merkmalen weicht jedoch der A dorsata Drohnensammelplatz von Drohnensammelplätzen der anderen Arten ab. $A$ dorsata Drohnen reagieren nur unter dem dichten und mächtigen Laubdach eines Baumes auf die Attrappen. A cerana indica Drohnen in Sri Lanka versammeln sich in eng durch das Geäst der Bäume begrenzten, nach oben offenen Räumen und fliegen dann mit direkter Sicht nach oben zum freien Himmel. A cerana japonica wurden über hohen Bäumen in Japan gefunden (Fujiwara et al, 1994) und A cerana cerana Drohnen, die aus importierten Bienenvölkern stammten, wurden auf einem Drohnensammelplatz von A mellifera in der Nähe von Oberursel in Deutschland gefunden (Ruttner, 1973). Damit sammeln sich die Drohnen von drei Rassen der A cerana sowie die europäischen $A$ mellifera Drohnen unter dem offenen, blauen Himmel (Jean-Prost, 1957; Zmarlicki and Morse 1963).

Die Ausdehnung des Drohnensammelplatzes von $A$ mellifera beträgt nach Radarmessungen etwa $1600 \mathrm{~m}^{2}$ (Loper et al,
1987). Das entspricht etwa der Ausdehnung des Laubdaches eines großen Baumes auf dem Drohnensammelplatz von $A$ dorsata. Die Sammelplätze von $A$ cerana dagegen scheinen sehr viel kleiner zu sein.

Große, herausragende Baumkronen bleiben für viele Jahre bestehen. So werden wir in den kommenden Jahren verfolgen, ob sich die Drohnen von $A$ dorsata regelmäßig in jeder Saison auf dem gleichen Drohnensammelplatz einfinden.

Für $A$ mellifera sind die Faktoren nach wie vor unbekannt, die dazu führen, daß die Drohnen jedes Jahr bestimmte Drohnensammelplätze aufsuchen. Damit ist die Beschaffenheit des $A$ dorsata Drohnensammelplatzes in Borneo als weithin sichtbare Landmarke einzigartig. Alle (fünf) herausragenden Baumkronen, die wir in unserem ebenen Versuchsgelände geprüft haben, wurden von $A$ dorsata Drohnen als Sammelplätze aufgesucht. Eine erste vorläufige Beobachtung an Nestern in einer Hanglage zeigte, daß hier eine Vorzugsrichtung der Drohnen talwärts vorhanden war.

Die hier vorliegende Publikation soll vor allem auch zu ähnlichen Versuchen und Beobachtungen in anderen Teilen des großen natürlichen Verbreitungsgebietes von $A$ dorsata anregen. Wir werden dann hoffentlich bald darüber Gewißheit haben, daß sich die Drohnen der Riesenhonigbiene generell unter der Krone großer, herausragender Bäume versammeln.

\section{DANKSAGUNG}

Wir widmen diese Arbeit Friedrich Ruttner zu seinem 80. Geburtstag am 15.Mai 1994 in Bewunderung seiner Verdienste um die Erforschung der Drohnensammelplätze. F Ruttner, der G Koeniger und N Koeniger 1965 auf dem Seekopfsattel, dem auch heute noch am besten untersuchten Drohnensammelplatz, in die experimentelle Forschung einführte, hat unsere Arbeit gefördert. Vor allem danken wir für seine Briefe nach Bor- 
neo, in denen er mit vielen guten Vorschlägen zur o a Entdeckung des ersten $A$ dorsata Drohnensammelplatzes beigetragen hat. Donson Simin, der Leiter der landwirtschaftlichen Forschungsstation in Tenom hat uns großzügige technische und logistische Unterstützung gewährt. Tadaharu Yoshida, von der Tamagawa Universität in Japan, hat unserer dringenden Bitte um Ausrüstung schnell entsprochen und uns ohne Verzögerung die für die Arbeit benötigten Dinge nach Tenom geschickt. Stefan Fuchs und Steve Sheppard haben mit vielen konstruktiven Vorschlägen zu einer Verbesserung des Manuskriptes beigetragen.

\section{Résumé - Les mâles d'Apis dorsata Fabricius 1793 se rassemblent sous la canopée des grands arbres à Bornéo.} Chez $A$ dorsata, un mâle produit 2 millions de spermatozoïdes et l'on a trouvé jusqu'à 6 millions de spermatozoïdes dans la spermathèque d'une reine qui pondait (Koeniger et al, 1990). L'accouplement multiple est donc évident chez $A$ dorsata. Mais on connaît peu de choses concernant leur comportement d'accouplement et on ne sait pas, entre autres, si les mâles se rassemblent en des endroits particuliers (lieux de rassemblement de mâles : DCA). Des expériences et des observations ont été faites de décembre 1992 à mars 1993 à la station de recherche agricole à Tenom (Sabah, Malaisie). Là, à la tombée de la nuit, les mâles s'envolent et quittent en grand nombre les colonies. Les mâles en vol produisent un bourdonnement distinct clairement audible. En suivant ce bruit plusieurs jours de suite il a été possible de localiser un premier lieu de rassemblement de mâles (DCA1) situé à $700 \mathrm{~m}$ de l'arbre où nidifiaient les colonies («arbre à abeilles») sous la canopée d'un arbre particulièrement haut (figs 1 et 2). Les heures de départ et d'arrivée des mâles à l'arbre à abeilles 1 et les heures de départ et d'arrivée au DCA1 concordaient parfaitement (tableau I). Afin d'avoir une preuve directe nous avons capturé quelques mâles et utilisé les techniques suivantes : i) les pièges à mâles (Taylor, 1984 ; Williams, 1987), mais ils ne se sont pas montrés performants ; ii) un leurre pour accouplement (Koeniger et al, 1989), préparé à partir d'une reine d' $A$ mellifera morte, a été présenté ; dans 5 essais au moins un mâle d'A cerana s'est accouplé avec le leurre et est resté collé (fig 3 ) ; iii) nous avons adapté l'étude de Fujiwara et al (1994) sur l'accouplement d'A dorsata en fixant à l'extrémité du leurre un morceau de ruban. Dans 5 essais plusieurs mâles ont été trouvés collés au ruban ; iv) nous avons fixé derrière le leurre un fil de coton recouvert d'une épaisse couche de colle. Trente mâles en moyenne ont été capturés par période de $5 \mathrm{~min}$. Sous la canopée les mâles étaient attirés par un leurre de reine imprégné de phéromone royale, mais les leurres situés à l'extérieur de la canopée ou au-dessus de l'arbre n'en ont attiré aucun. En outre les mâles étaient plus attirés quelques mètres en-dessous de la canopée (tableau II, fig 4). Le principal repère topographique du DCA1 est le grand arbre qui émerge. Nous avons pu repérer 3 autres arbres ayant ce même critère (fig 1). Sous ces 3 arbres le bourdonnement des mâles était audible à l'heure prévue et plusieurs mâles d'A cerana ont été capturés par la méthode du fil collant. Les DCA semblent être plus ou moins éparpillés dans les plaines. Lors d'une observation sur un flanc de montagne nous avons repéré un DCA en bas dans la vallée. En revanche aucun mâle n'a été trouvé sous les grands arbres à flanc de montagne. Les premiers DCA d'A mellifera décrits en Europe et aux ÉtatsUnis ont été découverts en écoutant le bourdonnement des mâles en vol (Jean-Prost, 1957 ; Zmarlicki et Morse, 1963 ; Ruttner et Ruttner, 1965a). Mais suivre jusqu'au DCA à l'aide du bourdonnement les mâles qui quittent la colonie n'a jamais été décrit. Cette nouvelle méthode est liée aux caractéristiques comportementales particulières des mâles d'A cerana: presque tous les mâles quittent la colonie simultanément. 
Des multitudes de mâles semblent s'éloigner en formations denses. Leur altitude de vol est suffisamment basse pour que l'on puisse détecter à l'oreille la principale direction de vol. En suivant le bourdonnement à partir de l'arbre 1 nous avons trouvé le DCA1 distant de $700 \mathrm{~m}$. Cette distance correspond bien à la durée d'un vol de $15 \mathrm{~min}$. Mais il faudra des expériences complémentaires et différentes pour tirer des conclusions sur la distance des vols d'accouplement. II faut marquer les mâles à la colonie et les recapturer au DCA ou vice versa (Ruttner et Ruttner, 1966). Chez les 3 espèces d'Apis ( $A$ mellifera, $A$ cerana, $A$ dorsata) les mâles se rassemblent au-dessus de certains lieux. Ce n'est que dans ces endroits que le bourdonnement des mâles en vol est audible. À l'intérieur d'un DCA, les mâles sont attirés et tentent de s'accoupler avec des leurres imprégnés d'acide céto-9 décène-2 oïque de synthèse. L'attraction des leurres présente un optimum à une hauteur donnée. De plus nos observations montrent que l'altitude optimale peut être en relation avec la hauteur de la canopée comme chez $A$ cerana à Sri Lanka (Punchihewa et al, 1990). Les mâles ne réagissent pas aux leurres hors des limites du DCA. Le DCA semble être visité par les mâles de nombreuses colonies alentour (Ruttner et Ruttner, 1966 ; Punchihewa et al, 1990). Ainsi le rôle d'un DCA en tant que mécanisme génétique qui évite la consanguinité semble commun aux 3 espèces. D'après les observations, les mâles d' $A$ cerana et les mâles européens d' $A$ mellifera volent par beau temps avec ciel dégagé (Jean-Prost, 1957 ; Zmarlicki et Morse, 1963), tandis que ceux d'A dorsata évitent les leurres de reines dans les endroits découverts et restent sous le couvert de la canopée. On ignore encore chez $A$ mellifera et $A$ cerana les facteurs du milieu qui déclenchent le rassemblement des mâles en des endroits spécifiques (Punchihewa et al, 1990 ; Ruttner, 1985). Le repère topographique clair et net du DCA d'A dorsata est donc unique. Nos expériences se sont limitées à Bornéo. Des observations sont donc nécessaires dans d'autres régions de l'aire naturelle de distribution d'A dorsata en Asie avant que l'on puisse conclure que les mâles de l'espèce d'abeilles la plus grosse se rassemblent généralement sous la canopée d'arbres particulièrement grands.

comportement reproducteur / vol / A dorsata / Bornéo / lieu rassemblement mâles

Table I. Drone flight time at bee tree 1 and DCA 1 based on the drone's hum.

Tabelle I. Drohnenflugzeit am Bienenbaum 1 und Drohnensammelplatz 1.

Date

\begin{tabular}{|c|c|c|c|c|c|}
\hline & Start & Return & Arrival & Departure & Weather \\
\hline 5.1. & 18.27 & $18.38-40$ & 18.28 & & Clear \\
\hline 6.1 . & 18.29 & $18.36-43$ & 18.30 & 18.43 & Clear \\
\hline 7.1. & 18.29 & $18.38-42$ & & & $75 \%$ clouds \\
\hline 8.1. & & no drone & & & Strong rain \\
\hline 9.1 & 18.27 & $18.39-43$ & 18.28 & 18.41 & Clouds, rair \\
\hline 10.1 & 18.32 & $18.43-46$ & 18.34 & 18.41 & Clear \\
\hline 11.1. & 18.30 & $18.39-43$ & 18.32 & 18.40 & $75 \%$ clouds \\
\hline 12.1 & 18.29 & $18.38-42$ & 18.31 & 18.40 & Clouds, rair \\
\hline 13.1. & 18.29 & $18.43-46$ & 18.31 & 18.43 & Clear \\
\hline 14.1. & 18.30 & $18.44-52$ & 18.31 & 18.51 (dummy) & Clear \\
\hline
\end{tabular}


Table II. Vertical distribution of $A$ dorsata drones at DCA 2, height of lowest branch $18 \mathrm{~m}$. Drones counted at dummies, 1 scan per minute; average of three experiments (28 Jan, $31 \mathrm{Jan}, 4 \mathrm{Feb}$ ).

Tabelle II. Höhenverteilung des Drohnenanfluges auf Drohnensammelplatz 2, Höhe der untersten Äste $18 \mathrm{~m}$. Anflüge auf Attrappe gezählt in $1 \mathrm{Scan}$ pro Minute. Mittelwert von drei Versuchen (28 Jan, 31 Jan, 4 Feb).

\begin{tabular}{|c|c|c|c|c|c|c|c|c|c|c|c|c|c|}
\hline \multirow{2}{*}{$\begin{array}{l}\text { Height } \\
m\end{array}$} & \multicolumn{12}{|c|}{ Minutes past $18.00 \mathrm{~h}$} & \multirow{2}{*}{$\begin{array}{l}\text { Total } \\
(\%)\end{array}$} \\
\hline & 42 & 43 & 44 & 45 & 46 & 47 & 48 & 49 & 50 & 51 & 52 & 53 & \\
\hline 18.5 & 0 & 0 & 1 & 2 & 1 & 1 & 0 & 2 & 10 & 1 & & & 3 \\
\hline 16.5 & 0 & 6 & 5 & 10 & 9 & 12 & 20 & 40 & 10 & 10 & 4 & 4 & 24 \\
\hline 14 & 5 & 8 & 12 & 20 & 20 & 15 & 15 & 10 & 15 & 25 & 25 & 15 & 34 \\
\hline 12 & 4 & 5 & 5 & 25 & 12 & 12 & 20 & 25 & 20 & 22 & 15 & 10 & 32 \\
\hline 10 & & 1 & 5 & 1 & 1 & 3 & 6 & 4 & 5 & 2 & 2 & 2 & 6 \\
\hline
\end{tabular}

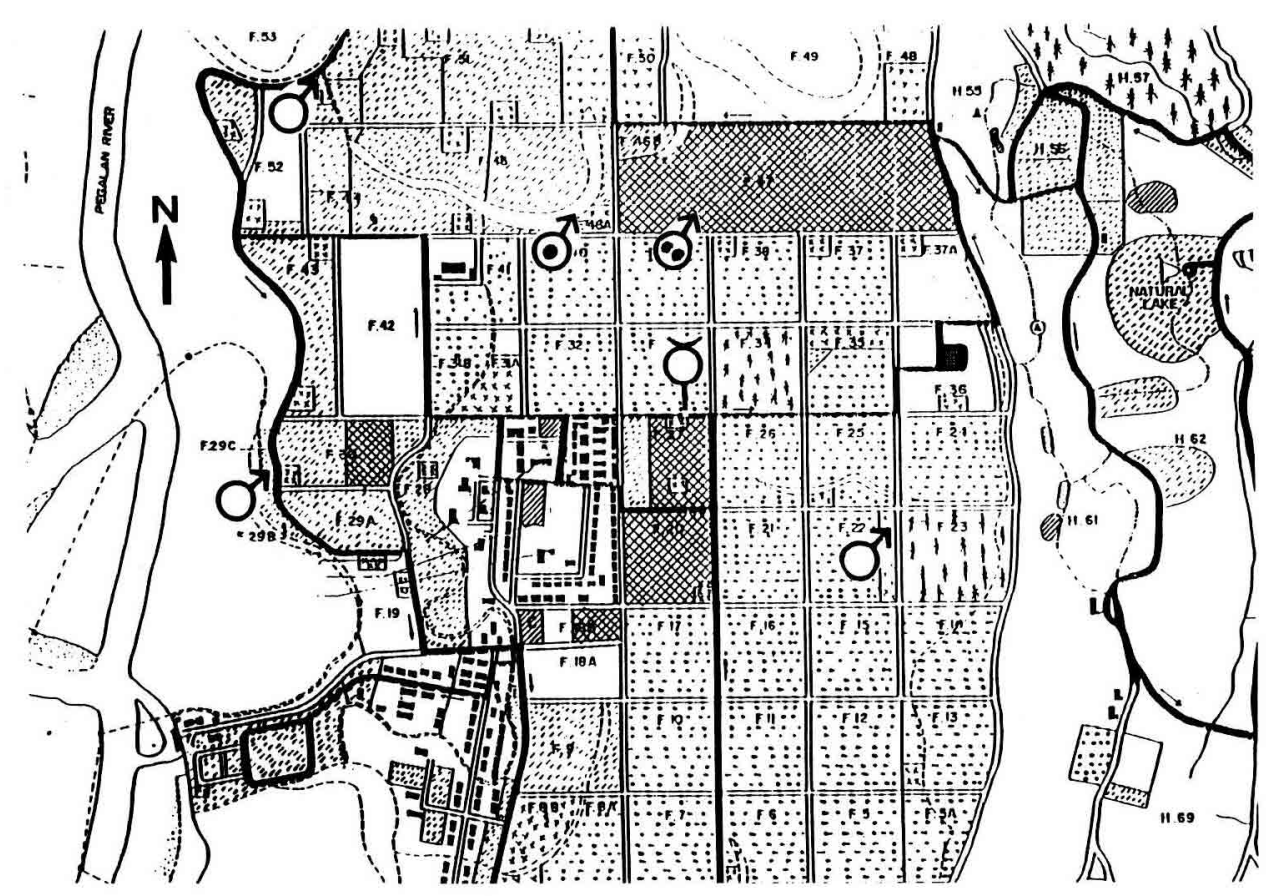

Fig 1. Map of ARS Tenom. $\not$, bee tree $1 ; \odot^{7}$, DCA $1 ; \odot^{7 \mid}$ DCA $2 ; \bigcirc^{7}$, other DCAs.

Abb 1. Lageplan des Versuchsgeländes. $\varnothing$, Bienenbaum $1 ; \odot^{\prime}$, Drohnensammelplatz $1 ; \odot$ Drohnensammelplatz 2; $\sigma_{b}$, andere Drohnensammelplätze. 


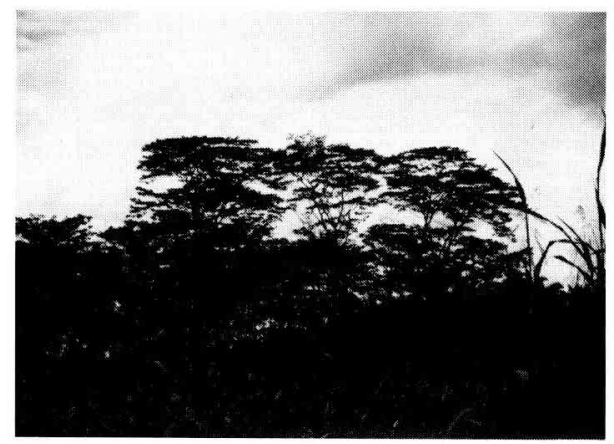

Fig 2. Three large trees emerge from the horizon (tree line). DCA 1 was found under the tree on the right side.

$\boldsymbol{A} \boldsymbol{b} \boldsymbol{b}$ 2. Drei große Baumkronen zeichnen sich am Horizont ab. Drohnensammelplatz 1 wurde unter dem rechten Baum gefunden.

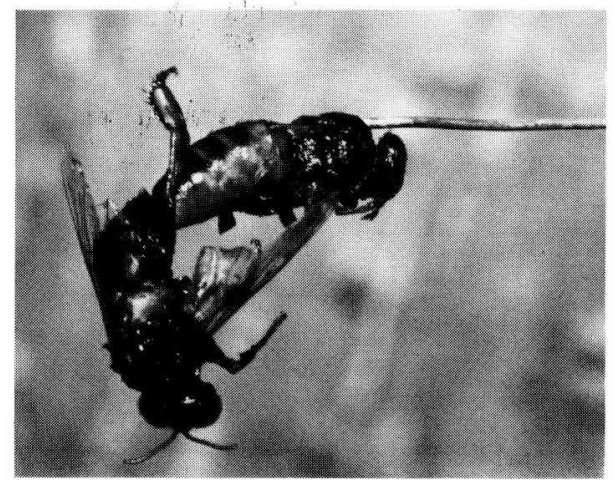

Fig 3. A dorsata drone copulated with an $\mathrm{A}$ mellifera queen carcass and got stuck with the everted endophallus.

Abb 3. Ein A dorsata Drohn hat mit der aus einer A mellifera Königin hergestellten Attrappe kopuliert und ist mit seinem evertierten Endophallus hängen geblieben.

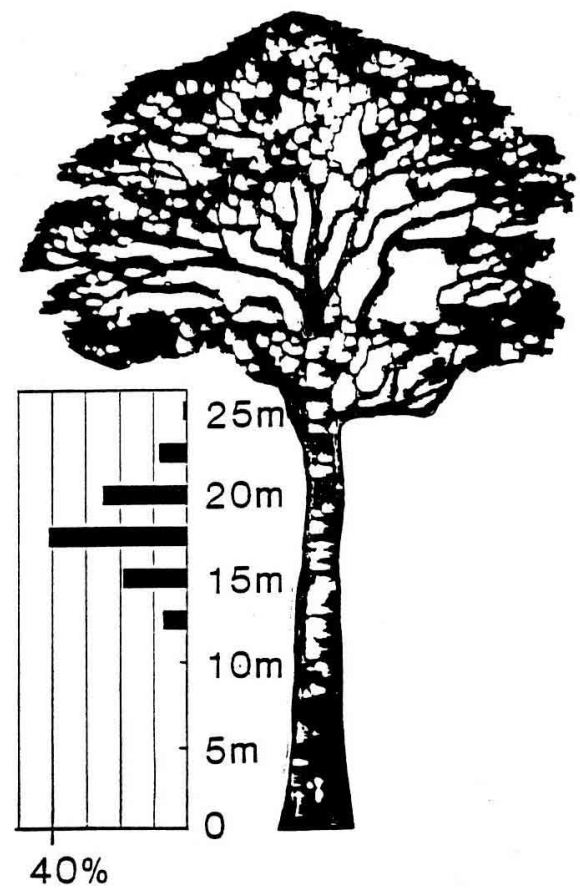

Fig 4. The canopy at DCA 1 and the vertical distribution of $A$ dorsata drones. (Drones counted at dummies, numbers indicate the average of two experiments ( 28 Jan and $30 \mathrm{Jan}$ ). The total num. ber of drones counted was 913.)

Abb 4. Die Baumkrone vom Drohnensammelplatz 1 und die Höhenverteilung der Drohnenanflüge. (Die Zahlen geben die Mittelwerte von zwei Versuchstagen am 28 Jan und 30 Jan an. Die gesamte Anzahl der Anflüge betrug 913.) 


\section{REFERENCES}

Corner EJH (1988) Wayside trees of Malaya. United Selangor Press, Kuala Lumpur, 3rd ed, $846 p$

Fujiwara S, Miura $H$, Kumagai T, Sawaguchi $T$, Naya S, Goto KT, Suzuki K (1994) Drone congregation of $A$ cerana japonica in an open area over larger trees (Zelkovia serrata). Apidologie 25 (3) (in press)

Jean-Prost $P$ (1957) Observations sur le vol nuptial des reines d'abeilles. C $R$ Acad Sci 245 , 2107-2110

Koeniger $\mathrm{G}$ (1988) Mating flights of honey bee drones (A mellifera) - a film documentation. In: The flying Honeybee (W Nachtigall, ed) Biona Report 6, 29-32

Koeniger G, Koeniger N, Pechhacker H, Ruttner $F$, Berg $S$ (1989) Assortative mating in a mixed population of European honeybees ( $A$ mellifera carnica, A mellifera ligustica). Insectes Soc 36, 129-138

Koeniger G, Koeniger N, Mardan M, Punchihewa RWK (1990) Numbers of spermatozoa in queens and drones indicate multiple mating of queens in $A$ andreniformis and $A$ dorsata. Apidologie 21, 281-286

Koeniger N, Koeniger G (1991) An evolutionary approach to mating behaviour and drone copulatory organs in Apis. Apidologie 22, 581-590

Koeniger N, Koeniger G, Tingek S, Mardan M, Rinderer TE (1988) Reproductive isolation by different time of drone flight between A cerana and $A$ vechti. Apidologie 19, 103-106

Lindauer M (1956) Über die Verständigung bei indischen Bienen. $Z$ Vergl Physiol 38, 521557

Loper GM, Wolf WW, Taylor OR Jr (1987) Detection and monitoring of honeybee drone congregation areas by radar. Apidologie 18, 163-172
Punchihewa RWK, Koeniger N, Koeniger G (1990) Congregation of Apis cerana indica drones in the canopy of trees in Sri Lanka. Apidologie 16, 201-208

Ruttner F (1973) Drohnen von Apis cerana auf einem Drohnensammelplatz. Apidologie 4, 41-44

Ruttner F (1985) Reproductive behaviour in honeybees. In: Experimental Behavioral Ecology (B Hölldobler, $M$ Lindauer, eds). Fortschr Zool 225-236

Ruttner F, Ruttner H (1965a) Untersuchungen über die Flugaktivität und das Paarungsverhalten der Drohnen. II. Beobachtungen an Drohnensammelplätzen. Z Bienenforsch 8, 1 9

Ruttner F, Ruttner H (1965b) Untersuchungen über die Flugaktivität und das Paarungsverhalten der Drohnen. III. Flugweite und Flugrichtung der Drohnen. $Z$ Bienenforsch 8, 332354

Ruttner F, Ruttner H (1966) Untersuchungen über die Flugaktivität und das Paarungsverhalten der Drohnen. IV. Zur Fernorientierung und Ortsstetigkeit der Drohnen auf ihren Paarungsflügen. $Z$ Bienenforsch $9,259-265$

Ruttner H, Ruttner F (1972) Untersuchungen über die Flugaktivität und das Paarungsverhalten der Drohnen. V. Drohnensammelplatz und Paarungsdistanz. Apidologie 3, 203-232

Taylor OR Jr (1984) An aerial trap for collecting drone honeybees in congregation areas. $J$ Apic Res 23, 18-20

Williams $\mathrm{JL}$ (1987) Wind-directed pheromone trap for drone honeybees (Hymenoptera: Apidae). $J$ Econ Entomol 80, 532-536

Woyke J, Ruttner F (1958) An anatomical study of the mating process in the honeybee. Bee World 39, 3-18

Zmarlicki C, Morse RA (1963) Drone congregation areas. J Apic Res 2, 64-66 